\title{
Museum Collections as a Reflection of Cultural Landscape: the Interpretation of Collective
} Memory

\author{
Oskar Habjanič \\ PhD Candidate MPhil, Regional Museum Maribor, Slovenia \\ Verena Perko
}

Assist. Prof., Phd, Phd, Regional Museum Kranj, University of Ljubljana, Slovenia

\begin{abstract}
The article deals with the relationship between the local community, museum collections, collective memory and the cultural landscape. The ICOM Code of Museum Ethics defines a museum collection as a cultural and natural heritage of the communities from which they have been derived. The collections, especially in regional museums, are inextricably linked to the community. The cultural landscape can be read also as a bridge between the society and natural environment. The cultural landscape is vitally connected with a national, regional, local, ethnic, religious or political identity. Furthermore, the cultural landscape is a reflection of the community's activities. Therefore, private collections are the foundation of the collective memory and empower museums for important social tasks. They offer an opportunity for multilayered interpretation of the past and give a possibility for museums to work on the inclusion of vulnerable groups. The collections could be a mediator and unique tool for recovering of the "broken" memory. In this way certain tragic past events, ignored or only bigotedly mentioned by history, can be re-evaluated.
\end{abstract}

Keywords: museum collections, cultural landscape, collective memory, inclusion, Regional Museum Maribor, Sveta Trojica v Slovenskih goricah

\section{Introduction}

\section{The cultural landscape as a narration of its inhabitants and the past}

This article is founded on the holistic concept of the contemporary heritological discipline, which interprets the landscape as a wholesome cultural phenomenon (Pirkovič, 2017). The cultural landscape is a palimpsest image of the inseparable human experience (the life and workings of man through time in his place of origin) and natural endowments, considering the climate as a reflection of anthropogenic activities, which becomes most apparent in the case of microclimatic conditions (Mlekuž, 2017). The landscape is the foundation of cultural heritage and the key to understanding related communities. Discovering, exploring, observing, and also evaluating and enjoying the environment, as well as, sadly, its destruction, are all part of the basic human activities. The understanding of cultural heritage, torn from the entirety of an environment, enables merely a partial and one-sided interpretation of the past, and opens a way for manipulative (political) interventions.

From a museological standpoint the holistic approach towards understanding cultural heritage, and consequently the landscape, has made a large contribution to the changes of content in the process of evaluating collections. Museum collections were and are emerging as a reflection of societal conditions, and are more or less the result of certain policies and social order, and last but not least of the social elites. They are (analogous to the museum artefact) object of scientific research, document of time,${ }^{1}$ and the foundation of a regional and national identity, which has a strong influence on their evaluation (Maroević, 1993, pp. 158 - 160). Private collections on the other hand reflect foremost the personal interests of the collector. In the process of a museum accession, the items undergo the processes of musealization, which most often means the partition of a collection based on the material and the scientific classification within the museum and its societal

1 Theodor Schmidt from Lenigrad University already in the year 1931 opposed the subjectivation of a museum item with a new definition as an object of scientific knowledge and a document of time (Maroević, 1993, p. 53). 
mission. A museum collection is divided into that what is kept in depots and rarely, if ever, visible to the public, and that which is incorporated into permanent or temporary exhibitions. Private collections are in the scope of the museum contexts usually presented to the public selectively and subordinate in the relations towards the context of a museum entirety and its social meaning. These are the factors that are reducing the value and esteem of private collections from a museum and the scientific interest viewpoint. With the new heritological concept, which perceives heritage (and not only museums) as a basic foundation of man's existence and discoveries (Šola, 2003), private collections have been given greater meaning, which is especially important for the eastern, formerly communist countries (V. Perko, D. Cerovski 2017). Private collections are a direct reflection of their collector's personal and often very focused perception of an item as a value and a material witness of its place of origin, and man's activities. They are usually not created from a scientific interest, but from a personal curiosity and an emotional favour. As such, they can crucially contribute to the broaden of an institutionalised perception, and they represent the bridging of the authorized heritage discourse, which is heavily present in the case of museum collections. Private collections are otherwise less important from the basic disciplines' standpoint. But they are reflecting at least some of marginalised groups and their values, thus enabling a more complete understanding of the past and landscape as a wholesome, socially natural phenomenon. From the museum collections aspect, they are presenting often overlooked or even consciously neglected themes, events, activities, sometimes also language ${ }^{1}$ and the values which may be of critical importance to a certain environment. Cases when private collections are connected to places of memory are vitally contributing to the preservation and the formation of the collective memory (Nora, 1984; Perko, 2016). The collective memory signifies a multilayered interpretation and a more wholesome understanding of the past, which indirectly enables a more democratic approach in the processes of managing heritage, and leads to a more equal society.

\section{Private collections and the cultural landscape}

The comprehensibility of a cultural landscape includes nearly all the areas of man's endeavours. The landscape is reflecting the cultural image of a certain region: it is a living organism of symbolic forms, an object of idolatry, and a muse of creative processes - especially that of artistry. The landscape is often a symbol of national identity, power, and authority; it is a part of tourism, environmentalism, and last but not least of politics. The European convention defines it as a bridge towards a common identity of peoples living in the area of a landscape, which by itself is complementing the now surpassed notion of the landscape as a home, a habitat, and a place of the former population's existence (Sassatelli, 2006, p. 192; J. Pirkovič, 2017).

The holistic concept of heritage enables us to understand the landscape as an inseparable part of man's environment. It is the result of natural endowments, the activities of man, and the human intellect (Milani, 2006, p. 125). The aesthetics of a landscape originates in the presumption that the experiencing of a landscape is determined by man and his values that, along with his feelings and emotions, run through him when experiencing the environment. The experience of a landscape is reflected in the artistic creation, sculpture, paintings, music... and also in its destruction, and is leaving a specific, palimpsest trace in all areas of man's activities (D. Mlekuž, 2017).

The landscape can be interpreted through different perceptions: metaphysics enables us to understand the landscape through landscape itself without the help of aesthetics or other philosophical disciplines, through its existence, which allows other disciplines to form a relationship toward it with its assistance. The metaphysical aspect of perception is largely a matter of a contemplative approach; its particular aspect of aesthetics that leads towards the formation of an entirely specific, spiritualised experience of phenomena, which science cannot encompass. Its phenomenology originates in an active relationship of man towards the landscape, "being in the world" it means to form a relation towards the world, to defend one's existence. Consequently, man has always gravitated towards things themselves, ready to create, to build. Heidegger speaks of a "house of being", through which man is only forming himself. It is a matter of dialectics between the object and the subject in the essence of being. Man is part of the landscape and the landscape is merely a part of man. The phenomenological aspect clearly sheds light on a museological problem unveiled decades ago - the problem of the objectified museum item, and consequently the collection as a part of the entirety of the environment (Maroević, 1993, p. 56).

\footnotetext{
1 In totalitarian societies, the so-called linguistic iconoclasm was often established, a process of "language purge" in which all politically unacceptable phenomena (and therefore also material culture) were named by new, neutral terms. A new specific terminology has emerged as a reflection of new social values.
} 
The result of the history of a landscape's perception is today best reflected through the art, which is triggering reminiscences of man's primary relationship between man and landscape (Kemal, 1993, p. 7). On the other hand, the landscape with the emergence of capitalism and a rapid, ruthless exploitation has become a subject of a profit-based logic and manipulation (Ross, 1993, p. 158). For the economist it possessed a real-estate value, for the sociologist it is a place of socialisation, for the architect it is a place in need of construction, the legal expert sees it as an opportunity to resolve a border dispute, the ecologist considers it as a natural habitat, the biologist as a region with biotic diversity. The archaeologist sees it as an archaeological site and a source of information on human's activity in the past.

Following Thomas Cook's expeditions, the discovery of Lake District, the crossing of the Alps, and the incorporation of the Italian peninsula into the "Grand Tour", when discoveries are being familiar with the cultural landscape of the Renaissance Italy became part of the educative process of European elites, the concept of landscapes shifted towards the field of aesthetics, philosophy, and science (Schnapp, 1996).

Rationalism and empirism of the contemporary era brought about the triumph of man over nature, which began with Newton, Descartes, Bacon, Leibnitz, and has manifested itself in the rapid evolution of technology and industry (Sloterdijk, 2003). The domination over nature and the manifestation of power reached its zenith with the destruction in the last few decades of the $20^{\text {th }}$ century that followed the conquest of technological obstacles at macro- and microcosmic areas, unattainable and unknown to the man of the $19^{\text {th }}$ century. In the name of ideals, and in the last decades mostly in the name of consumerism and capital, the landscape has become an object of entertainment and a ruthless exploitation. Jean Baudrillard with his theory of simulacrum most direly expressed the situation. He finds that the contemporary man has lost touch with reality (by which he means nature), and replaced it with an artificial image, the simulacrum. Built upon (artificial) images and models it creates a world of hyperreality, a world more real than the actual world. To make things even more grotesque, Baudrillard adds that the purpose of the simulacrum is primarily a total control. Social and natural sciences are often an excuse for man's exploitation endeavours, even towards the landscape (Baudrillard, 1988). Museums, at least those more traditional ones, serving foremost the interests of science, with a museological instrumentalization of collections and items are indirectly promoting science and imperialistic, colonial principles of the western world (Šola, 2003).

In art history, we encounter two different paradigms: for the notion and reality, or for the relationship between the image of a landscape, and a referent in the real world. The question is, whether or not this is the image of a landscape or the image of an painting, or the aforementioned aesthetic view on the perception of the landscape.

Archaeology is perceiving a landscape as a container and the past as a large cake with separate historical periods of time. The needs of the current scientific paradigm are usually dictating contents and modes of interpretation of the past. Museums are uncritically adopting scientific paradigms in which nature, including the animal world, is the object of research. They focus solely on its aspects of use, and their depiction as a raw material. Are we allowed to claim that an uncritical adoption of the scientific concept in processes of musealization leads toward the objectification of material culture in the role of a museum item (Maroević, 1993, p. 56)?

Anthropology, sociology and history treat the landscape as an open social unit in which man expresses his different beliefs. However, we know today that the landscape is not merely a single place but a sum and a mutual insemination of different places (Pirkovič, 2017). The landscape has to be interpreted through a space as a typology of place through an intersection of time (Perko, 2014, p. 169). It may also repeat, naturally in another time and place, and in the light of transformed values. Each landscape is exclusive, unique, that cannot repeat itself in a certain time period. As emphasised by James McGlade, it is necessary to view the landscape as a social construct trackable through history (McGlade, 1999, p. 475).

Stephen Daniels interprets the meaning of the landscape through identity processes. He claims that the mutual national identity is the product of the age of national states. National identities are accompanied by metanarratives, anecdotes, legends, stories of "the golden age", unique landscapes are depicting the nation, symbolise its spirit, its ethos. The landscape functions like a national icon; it is a reflection of ideology (Daniels, 1993).

Of paramount significance are also the communication networks through which the cultural landscape is enabled, maintained, and transferred. In it various ecological dynamics are inscribed as the result of the activities in different layers, different social formations of inhabitants. Each changes in human nature influences the ecodynamic structures and reflects in the image of the landscape. The change of the landscape is inseparably connected to the change in behaviour (McGlade, 
1999 , p. 475) as a complex reflection of beliefs, systems of value, and the pragmatic responses to the everyday environment.

Simon Schama is connecting the landscape to memory. The landscape is a product of man's consciousness and allows us to understand man's role in the world (Schama, 1995, 9.7). The internalised historical memory leads to identifying with the landscape. It allows for the discovery and the understanding of a part of that which we once already were. Man simultaneously takes notes and discerns the landscape as his own memory of the past (cemeteries, memorial parks, plague memorials, sacred structures,...), with its assistance he builds upon myths and his own glory, letting everybody else and our descendants know of his presence and dominance. The landscapes tells stories to those willing to listen. Each landscapes carries within itself a unique history that allows the place to become something special, to become sui generis; it accumulates memories and emotions in certain place and time. It is a place of both private and collective property. Today the landscape is all but objectified, adapted to culture, empirical sciences, and thusly trapped in the mechanisms of valuation of the contemporary consumer society and its needs. ${ }^{1}$ In its philosophical and psychological dimension and due to its palimpsest nature it is only partially intelligible to the scientific disciplines. The landscape is first and foremost a place of collective memory (Halbwachs, 2001; Nora, 1984).

For a wholesome perception of the landscape and its palimpsest intertwined meanings and values through time it is necessary to view it through the "eyes" of the local population. This aspect is uniquely allowed by private collections, which are usually created without the presence of large influences of scientific concepts and methods, and are not exposed to the authorized heritage discourse, maintaining the subjective role of an item.

\section{The museum collection and identity}

The International Council of Museums (ICOM) in its code emphasised that museum collections mirror the cultural and natural heritage of the community in which the items originate. The collection comes into being insofar it as a representative value, or is tied to an idea, or is merely a part of a greater whole (Durost, 1932, p. 158). We may then speak of a certain planned collection policy. Russell W. Belk a good half century later finds that the collecting process has to be an active, selective, and a long-term one (Belk W., 1994, p.158).

Museology in the 70 s of the previous century has established the museum item as an information-documentation object, part of the INDOK System, it assigned to it the role of a cultural information messenger (Tuđman, 1983, pp. 73-80), upgrading the needs of the scientific realizations of fundamental scientific disciplines (Maroević 1993, p. 58). By definition from Maroević the cultural information gives value to a museum item, and more or less tightly connects it to the national, regional, local, ethnic, religious, or political identity.

The heritage movement that appeared as a response to groundbreaking social changes of the $60 \mathrm{~s}$ in the $20^{\text {th }}$ century shocked traditional museums with the revolutionary idea of the ecomuseum as a form of a holistic interpretation of place (Šola, 2010). The idea eventually spread to the rest of the world and in some parts, it became a successful practice of preserving heritage in the place of origin.

The ecomuseum's philosophy is based on an active inclusion of the public and is a multiinterpretation of a place (Šola, 2003). The local population is the bearer of heritage processes, which are, based on the traditional way of life, while the expert services adopt the role of advisors. In the concept of the ecomuseum the private collections have been granted a similar role as the local public: from a previously passive role of a side observer it adopted the role of the agent, the subject by means of active inclusion. Similarly, this also applies to the role of ecomuseum collections, which become the subject

\footnotetext{
${ }^{1}$ Božidar Kante perceives the landscapes as artefacts offering answers from the past, through which they are subjected to the will and the shaping by man. By artefact he understands an item changed by labour, that is what does not originate in the natural state. The other meaning is connected to the cultural process, which demands further interpretation. In the first sense we are dealing with two different artefacts; a thing that was, and a thing that was subsequently changed. The second one's form remains unchanged. He understands the landscape not only as a territory or a scenery, but also as an alliance of communities, justice, nature, and environmental endowments, that is as a social dialogue, as an "alliance" of man and landscape (Kante, 2009, p.14).
} 
and an important element of collective memory. They are most often also a physical, symbolic, and functional witness of places of memory / lieu de mémoire. ${ }^{1}$

Private collections in the process of landscape interpretation have thus been assigned a key role, which is otherwise denied to them by the traditional museological doctrine and the authorised heritage discourse. Private collections frequently mirror alternative political and social viewpoints, and are a reflection of religious and ideological beliefs, or they reflect a special, often intimate and unspoken relationship of their owner towards the world and society. Private collections represent a peculiar preserved microcosm in the often highly corroded macrocosm of museums. Unlike museum collections, private collections are not ordinarily divided to depot and exhibition material. In many cases they are equipped with a very personally conceived catalogues and informative notes, which preserves the original folk terminology. Sometimes they are created out of the owner's special interest in an area which from the authorised heritage discourse's viewpoint has been neglected or even overlooked. In these cases, the collections are accompanied by the owner's exhaustive knowledge on matter, which represents a valuable alternative to institutionalised standpoints.

Private collections are the key to "discerning" and understanding the landscape. They are the material foundation of a collective memory, because they preserve specific values and lore tied to places of origin. Collections of artefacts are not only a document of time and space but also a reflection of a specific, personal relationship towards the social and natural environment, and they preserve crucial knowledge not ordinarily encompassed by scientific methods. This is mostly the socalled convivial knowledge according to Ivan llich, that relate to inherited observations of the environment and the society, and are most often reflected in specific concepts, forms, decor, or in ways of use with a certain material culture. Convivial knowledge is frequently and inseparably tied to the place of origin and is implicitly encompassed in contexts of use and related customs (Perko, 2018).

\section{Case study: the museum collection of the Franciscan monastery at Sveta Trojica in Slovenske gorice}

The Franciscan monastery in Sveta Trojica in Slovenske gorice is located in the Northeast part of Slovenia. The region with the monastery and a church was already mentioned in 1445 CE in documents as Verchoczen - Vrhovšaki. During the church's construction the name Purkstallberg (also Purggstallberg), that is Porčki vrh (after a nearby settlement) became common, and among the locals in the midst $17^{\text {th }}$ century the name Grädisch, as a synonym for the Slovenian name Gradišce (Habjanič, 2014, p. 70; Vidmar, 2016, p. 91), was in use. On a hill rising above the Drava river basin and the nearby town of Lenart, a wooden chapel dedicated to the Holy Spirit was built in $1631 \mathrm{CE}$. It soon became too small to accommodate the needs of the locals, therefore in 1636 the foundation stone was laid for a church finalised in 1640 or 1643, and dedicated to the Holy Trinity. With the arrival of Augustinian eremites in 1663 the construction on a monastery began, followed by several reconstructions of the entire sacral facility. The extensive reforms of Emperor Joseph II., affecting the Church, brought about the abolishment of many monasteries in Austrian lands. In 1787 the Augustinian monastery was shut down, a year before the parish of Sveta Trojica was already founded, and spiritual care was taken over by priests from the nearby parish of St. Lenart. In 1854 Franciscans arrived to the parish who manage the monastery and the church to this day. The prominent position of the structure and its size left a mark in Slovenian literature as "the Slovenian Jerusalem", and is considered the most beautiful Baroque sacral complex in today's Lavantinska bishopric (Mlinarič, 1996, p. 68).

The church with its monastery gives the region as the landmark a characteristic position and recognisability. Around the church and the monastery, a settlement gradually sprang to life, which in 2006 became an independent municipality with three distinguishable bell towers in its coat of arms. The church in the very beginning adopted the role of a pilgrim destination, and among the most important pilgrimages we should mention the spring pilgrimage on St. Florian's name day, the Pentecost pilgrimage on the Holy Trinity day, the August pilgrimage on Porcijunkula, and the Autumn pilgrimage on fourth Sunday. This lead to the appearance of smaller and larger town fairs that connected local inhabitants to the church.

\footnotetext{
${ }^{1}$ Lieu de mémoire is a concept related to collective memory, stating that certain places, objects or events can have special significance related to group's remembrance. Pierre Nora defines them as "complex things. At once natural and artificial, simple and ambiguous, concrete and abstract, they are lieux - places, sites, causes_-in three senses-material, symbolic and functional".
} 


\section{The Franciscan monastery museum collection in Sveta Trojica in Slovenske gorice}

Items relating to the monastery collection have been finding their way into the monastery museum for centuries. The collection encompasses 1060 artefacts, ${ }^{1}$ along with an extensive library with over 1550 books. ${ }^{2}$

The Sv. Trojica monastery museum collection could be thematically divided into several parts. Liturgical garments of 497 artefacts, such as chasubles, albs, dalmatics, pluvials, stoles, maniples, pales, purses, vela, and banderas, form its basis. The oldest ones originate in the $17^{\text {th }}$ or $18^{\text {th }}$ century, while the youngest dated are still in everyday use. After the dissolution of the Augustinian monastery in 1787 most of the chasubles was transferred to the parish churches in Maribor, Sv. Lenart, and Sv. Marjeta. The largest part of the items still kept in the monastery was not received until the arrival of the Franciscans in $1854 .^{3}$

The second part of the collection entails votive paintings from the $17^{\text {th }}$ and $18^{\text {th }}$ century and they divulge the significance of the Sv. Trojica church as a pilgrimage center. Among them several supplication of pilgrims from the region of contemporary Austria, the city of Strass, St. Peter im Sulmtal, Wagendorf beim Vogau have survived, the most important being the supplication of the count Szapari from 1761 who lived in Murska Sobota at the time, and supplications of believers from Radgona and Slatinski dol.

A part of the museum collection also represents collection of paintings. It largely entails works from the $19^{\text {th }}$ and $20^{\text {th }}$ century which arrived to the monastery mostly at the same time the Franciscans did, as well as valuable smaller sculpture works from the $18^{\text {th }}$ century which were removed from the church and transferred to the museum. The sacral art collection also encompasses reliquaries and liturgical vessels.

A special attention in the museum was devoted to the Black Madonna with Child, a work by an unknown sculptor, supposedly dated to the $17^{\text {th }}$ century, which was found in the Loretan chapel,-annexed to the church in the $17^{\text {th }}$ century. The sculpture was located in the interior part of the "secundary" Black Madonna from the $19^{\text {th }}$ century as part of the altar. A crown from allegedly the $17^{\text {th }}$ century has also survived, and was assigned to the Madonna's ornament from the $19^{\text {th }}$ century.

Economic endeavors of the monastery are evident through vineyard and wine-making implements, numerous barrels, and other agricultural tools, which was not only a part of the monastery life, but also of the surrounding inhabitants, who still nurture the wine production with great enthusiasm today. A part of the museum collection is connected to the Holy Trinity and other pilgrimage destinations. In some contexts many devocionalia, sacred images, and items from pilgrimage centers brought to the monastery by different people, vicars and the surrounding inhabitants have also survived. We should also mention the many banderas which are related to the pilgrimages from nearby settlements, mostly Radgona and Lenart, and church processions.

The deep connection of local inhabitants with the monastery is also evident in the richly preserved photographic material documenting important events from the time of the Franciscans, both secular and otherwise, that are revealing the popularity and the important role of the monastery among the local community. The collection comprises also items pertaining to the activities of the girl's religious group of Marijina družba pri Sv. Trojici, the items of boys section of religious society - Crusaders at Sv. Trojica, as well as many Franciscan ring seals dating back to the second half of the $19^{\text {th }}$ century.

The monastery library keeps over 1550 books. The archive arrived to the Sv. Trojica monastery in the second half of the $20^{\text {th }}$ century. It was part of the repatriation of the archives confiscated by the German Army during World War 2 and as a war booty transported to Graz. The archive was originally part of the Franciscan monastery Brežice's library in the SouthEastern part of Slovenia, where there a Boys school existed from 1668 onward. Two $15^{\text {th }}$ century incunables and over 30

\footnotetext{
1 The collection was documented in field work by Oskar Habjanič, Tadej Pungartnik, Maja Hren Brvar between November 2012 and April 2013. The field registry is located in the Regional Museum Maribor under the number RT 2012-4.

2 The information on the Sveta Trojica in Slovenske gorice monastery library was kindly relayed to us by our esteemed colleague dr. Vlasta Stavbar from the University Library Maribor, for which we thank her sincerely.

${ }^{3}$ Written sources mention extensive supplications pilgrims relayed to the graceful image. The intercessions reveal both a noble and a peasant and market social class of the surrounding inhabitants. For more on this see: Oskar Habjanič, Avguštinski samostan v Slovenskih goricah v dobi baroka, p. 70, in: Kronika, časopis za slovensko krajevno zgodovino, 62/1, 2014, p.67 - 90. Among the main church and monastery patrons once should mention the Stubenbergs, Trauttmansdorffs, Khisls, and probably the Draškovičes.
} 
manusripts and books from the $16^{\text {th }}$ century survived in the collection. Among the rarities one should mention the book on physics from 1574 and vast archive from the 18 th century, printed in Ljubljana (Stavbar, 2014).

The tourist attraction trail includes the church with the monastery, in which the central role has been adopted by the miracle image of the Holy Trinity from around 1690. The main altar with the Augustinian Order saints (St. Thomas of Villanova, St. Augustine, St. Nicholas of Tolentino, and St. John of Facundo) was made in the mid-18 ${ }^{\text {th }}$ century. The side altars date back to the time of Augustinians and Franciscans in the second half of the $19^{\text {th }}$ century. Among the altars one should point out the altar of the Holy Cross with a depiction of the crucifixion of Jesus, allegedly the work of the excellent Baroque master J. M. Kremser Schmidt. The sculptures have been attributed to various Styrian artisans. The Loretan chapel was annexed to the church in 1693 and was built by donations from the countess Mary Elisabeth Trauttmansdorff, born countess Khisl. The organ dating to 1833 and made by Karl Schehl from Graz is also a part of the church furnishings.

\section{The current arrangement of the museum collection}

The museum collection was displayed in the monastery, and the monastery library has also been included in the exhibition tour. Individual items are placed in different custom made display cases, some in segments, others along the room's wall. Among them we find photographs and postcards revealing the activities of the girls religious study group at the Marijina družba pri Sv. Trojici, and the boys section of religious society - the Holy Trinity Crusaders. A distinct display case holds priest robes, sacral art, and pilgrim devotionalia and accessories. On the walls are displayed votive paintings, and on the side and the upper part of display cases there are items from the monastery's and of the local community economic life.

The museum collection is didactically organized according to the $19^{\text {th }}$ century museum principles. Individual segments are reminiscent of a Kunstkammer, known to us from the court life between the $17^{\text {th }}$ and $19^{\text {th }}$ century. The current collection placement is not enabling a sufficient recognisability and narrativeness of otherwise extraordinary artefacts, and is neglecting a more intensive communication with the local environment.

The identity of the town is therefore "only" based on sacral architecture masterpieces of the Baroque era, which was successful in constructing a bridge between the landscape and the community by the placement of recognisable bell towers, which transcends the understanding of the landscape either as a scenery or a territory (Kante, 2009). In this context one could recognise a dialogue between man and the landscape: the latter has become a recognisable symbol of the town, a landmark and an imago tailored according to man's actions. It has become an active heritage of past deeds (Beneš, Zvelebil, 1999, p. 74).

\section{Museum collection as a dialogue between a cultural landscape and the community}

The Regional Museum Maribor in 2013/2014 organised the exhibition The Treasures of the Holy Trinity, based on the collection from Sveta Trojica. ${ }^{1}$ The temporary exhibition was placed in rooms of the Regional Museum Maribor (The Partisan Cinema). Thematic segments of the exhibition were tied to liturgic garments. The significance of the chasubles, garments, and symbolics (colours, pattern interpretation, dating) was emphasized, and of the pilgrimage in relation to the items (the Loretan Black Madonna, votive paintings and reliquaries). The history and the history of the monastery was presented by the sculpture collection, while the economic significance of the monastery was relayed on working tools and implements. As a part of the exhibition, thematic lectures from the various fields of theology and sacral art were organized. ${ }^{2}$ The exhibition was visited by the entire elementary school of Sveta Trojica in Slovenske gorice. There was an organised field trip from Maribor to Sveta Trojica. Additionally, in cooperation with the school nurses of Sv. Frančišek Kristus Kralj several workshops were organised themed Embroidering with a Golden Thread, as a demonstration of how a priest robe is made, and for the purpose of the exhibition restoration - conservation works were performed on artefacs, which were also presented at the lecture.

The museum exhibition took on the role of a contact zone, ${ }^{3}$ a meeting point and complementing the collective memory. It was focused on dialogue and designed as a process that forms relations with interaction among the contents, artefacts,

\footnotetext{
${ }^{1}$ Authors of the exhibition: Oskar Habjanič (project leader), Maja Hren Brvar and Tadej Pungartnik.

${ }^{2}$ Lecturers to be mentioned: ddr. Nataša Golob, dr. Edvard Kovač, Irena Porekar Kacafura, Tadej Pungartnik, Oskar Habjanič.

${ }^{3}$ For a more detailed role of museums as contact zones see James Clifford, Museums as Contact Zones, in: David Boswell and Jessica Evans (ed), Representing the Nation: A Reader: Histories, Heritage and Museums, Routledge, The Open University, 1999, pp. 435 457.
} 
place of origin, and the public. The basic characteristic of the meeting point became the reciprocity (Clifford, 1999, pp. 437 -441) between the museum item and the visitor, who was encouraged by the museum item through memory of past events to strengthen the feeling of belonging and related emotions. In the case of The Treasures of the Holy Trinity exhibition memories of pilgrimage are strongly connected to farewells and loss.

The exhibition concept was based on inclusion and an active participation of the community. The society of countryside women from Sveta Trojica prepared a small banquet at the opening ceremony, while the children choir of Sv. Trojica took part with a music program. Individual thematic segments of the exhibition emphasised the significance of the museum item as a narrator of the past (Pearce, 1994, pp. 19 - 29) at which, according to Saussur, a relationship was established between the designator and designatee (Saussure, 1997), between the museum item or the collection and the community, between the object and the subject. The exhibition narration restored an active role to the museum item in the local community and subjectified it through the interpretational structure of the museum collection.

The name of exhibition The Treasures of the Holy Trinity carried a powerful message, and at the same time it functioned as a metaphor and a symbol, or a sign on which the exhibition entirety through interpretation was based upon, while the community recognised itself in it. The title triggered a process of communication and strengthened the interaction between the monastery collection and the community. We can identify it as a repeating cycle among the designator - designatee sign, through which new social bonds are triggered and formed (Pearce, 1994, p. 25).

\section{Conclusion}

The museological problem of the objectifying a museum item was already addressed decades ago (Maroević, 1993, p. 53). The problem can also be identified in the relationship of museums towards private collections. From a phenomenological viewpoint, which emphasises dialectics between an object and a subject, captured in the essence as well as the existing, one can shed a lot of light on the exposed problem. From this viewpoint the role and the meaning of a museum item are inherently encompassed in the entirety of the place of origin. The musealization of an item in the holistic conceived context with its varaiety of meanings and values means the subjectification of the item. On the other hand the dislodging of an item from its contexts of origin bring about its objectivisation. Symbolically one could speak about the process of "personalization" and "depersonalization" of a museum item, which in an analogue sense also applies to collections.

Private collections from the good practice examples viewpoint mean the material connotation of the collective memory. They enable additional, alternative insights into the subject and are incorporating multiplicity into the interpretation of the past. They reflect values, beliefs, and behavioural patterns that museum collections, subordinated to the principles of scientific research, do not entail or plainly miss. Private collections are not exposed to the authorised heritage discourse and enable a multi-interpretative and inclusive manner of managing heritage. From the museological theory, we can conclude that they enable the subjectivization of items in the processes of musealization as an inherent part of the place of origin.

We can conclude with the statement that a holistic heritological approach is in fact improving the understanding of the social role of private collections, which are presenting often overlooked or consciously neglected values, events, and activities in museums. Along with the places of memory they indispensably contribute to the preservation and the shaping of the collective memory, which in certain social environments enables a more democratic approach in the processes of heritasation and heritage management, and by doing so, a more wholesome understanding of the past.

\section{References}

[1] Pirkovič, Jelka (2017): Koncept kulturne krajin in vloga muzejev pri njenem varstvu / The concept of cultural landscape and museums' role in its conservation, in: Perko, V., Terčon, N. (eds.), Museums, heritage and cultural landscape: Acta. Radovljica: Slovenian Museum Association; Ljubljana: Slovenian Museum Confederation; Celje: ICOM, National Committee of Slovenia, pp. 27-39.

[2] Mlekuž, Dimitrij (2017): Zapletene krajine so demokratične krajine / Complex landscapea are democratic landscapes, in: Perko, V., Terčon, N. (eds.), Museums, heritage and cultural landscape: Acta. Radovljica: Slovenian Museum Association; Ljubljana: Slovenian Museum Confederation; Celje: ICOM, National Committee of Slovenia, pp. 41-46.

[3] Maroević, Ivo (1993): Uvod u muzeologiju, Zagreb: Zavod za informacijske studije. 
[4] Šola, Tomislav (2003) Eseji o muzejima i njihovoj teoriji: Prema kibernetičkom muzeju, Zagreb: Hrvatski nacionalni komitet ICOM.

[5] Perko, Verena, Cerovski, Dijana (2017): Balkans between East and West : the social responsibility of heritage interpretation : (through the panopticum of the heritage musealisation). in: Interpret Europe: Spring Event Proceedings, pp. 19-21 May 2017, Prague. [Prague]: Interpret Europe. 2017. http://www.interpreteurope.net/fileadmin/news-tmp/ie-events/2017/Prague/ieprague17_proceedings.pdf.

[6] Nora, Pierre (ur.) (1984-1992) Les Lieux de Memoire I-VII, Paris: Editions Gallimard.

[7] Perko, Verena. Muzeji in prostori spomina, in: Petras, Tina (ed.), Kramberger, Taja, Babšek, Jana, The politics of memory and oblivion, modes of transmission and interpretation: proceedings of the symposium coinciding with the 70th anniversary of the Ljubelj/Loibl camp liberation, held 11-12 June 2015 at Tržic Museum, Tržic, Slovenia. 1th ed. Tržič: Tržiški muzej. 2016, pp. 209-219.

[8] Sassatelli, Monica (2006): Sociable Europe as Landscape: Insights from the European Landscape convention aestetics of bodily senses, in: Imaginacija, čutnost in umetnost: Zbornik referatov III. Sredozemskega kongresa za estetiko, Portorož, Slovenija, 20 - 23. September, pp. $192-197$.

[9] Milani, Raffaele (2006): Aestetics of the Mediteranean Landscape, in: Imaginacija, čutnost in umetnost: Zbornik referatov III. Sredozemskega kongresa za estetiko, Portorož, Slovenija, 20 - 23. September, pp. 124 126.

[10] Kemal, Salim (1993): Nature, fine arts, and aesthetics, in: Landscape, natural beauty and the arts (ed. Kemal, S., Gaskell, I), Cambridge University Press, pp. $1-42$.

[11] Schnapp, Alain (1996): The Discovery of the Past: The Origins of Archaeology, London: British Museum Press.

[12] Ross, Stephanie (1993): Gardens, earthworks, and environmental art, in: Landscape, natural beauty and the arts (ed. Kemal, S., Gaskell, I), Cambridge University Press, 1995, pp. 158 - 182.

[13] Sloterdijk, Peter (1988): Critique of Cynical Reason, Minneapolis, University of Minnesota Press, 1988.

[14] Baudrillard, Jean (1988) Simulacra and simulations: Selected Writings (ed. M. Poster), Cambridge: Polity Press, pp. 166-184.

[15] McGlade, James (1999): Archeology and the evolution of cultural landscapes: towards an interdisciplinary research agenda, in: The Archaeology and Anthropology of Landscape (ed. Ucko, Peter J., Layton, Robert), Routledge, pp. $458-471$.

[16] Daniels, Stephen (1993): Fields of Vision: Landscape Imagery and National Identity in England and the United States, Princeton University Press, 1993.

[17] Schama, Simon (1995): Landscape and Memory, Toronto: Random House of Canada.

[18] Kante, Božidar (2009): Estetika narave, Sophia.

[19] Halbwachs, Maurice (2001): Kolektivni spomin, Studia humanitatis, Ljubljana: ŠKUC, Filozofska fakulteta.

[20] Durost, Walther (1932): Children's Collecting Activity Related to Social Factors, New York, Columbia University, 1932, quoted in: Pearce, Susan M. (1994): Interpreting Objects and Collections, Routledge.

[21] Belk, Russel, W. et al (1994): 'Collecting in a consumer culture', Highways and Buyways, Utah: Association for Consumer Research, quoted in: Susan M. Pearce, Interpreting Objects and Collections, Routledge 1994, pp. $317-326$.

[22] Tuđman, Miroslav (1983): Struktura kulturne informacije, Zavod za kulturu Hrvatske, Zagreb.

[23] Šola, Tomislav (2010): The Museum Definition: Questioning the Scope and Motives, in: A. Davis, F. Mairesse, F. Desvallées (ur.) What is a Museum?, München: Verlag Dr. C. Müller- Straten, pp. 106-112.

[24] Perko, Verena. O vlogi kulturne dediščine pri oblikovanju identitete in pomenu konvivalnih znanj, ki jih muzeji posredujejo. In: Krapše, Štefan (ed.). Šola in muzeji v evropskem letu kulturne dediščine = Škola i muzeji u evropskoj godini kulturne baštine : e-zbornik. Nova Gorica: Educa. 2018, pp. 5, 29, 64-67.

[25] Habjanič, Oskar (2014) Avguštinski samostan v Slovenskih goricah v dobi baroka, in: Kronika, časopis za slovensko krajevno zgodovino, 62/1, pp. $67-90$.

[26] Vidmar, Polona (2016): Cerkev Svete trojice v Slovenskih goricah in njeni donatorji. Stubenbergi, Trauttmansdorffi, Khisli, čudodelna podoba in motiv calcatio, in: Zbornik za umetnostno zgodovino, LII/2016, pp. $85-118$.

[27] Jože Mlinarič, Župnija Sv. Lenart do jožefinske dobe, in: Zbornik občine Lenart. Published at 800th anniversary of the first written mention of Lenart (edit. Slavko Kramberger), Lenart, 1996, pp. $63-71$. 
[28] Stavbar, Vlasta (2014): Knjižnica v Frančiškanskem samostanu Sv. Trojica v Slovenskih goricah; Sobratom svojim v dediščino milo, Scientific symposium on the 500th anniversary of the Slovenian Franciscan province of Sv. Križ, Franciscan monastery Ljubljana - center, Frančiškova dvorana, 12. and 13. september 2014. A more detailed list of the book material: p. Felician Pevec, Brežice monastery library, in: S patri smo sibili dobri. Tri stoletja brežiških frančiškanov. Krško, Ljubljana, 2013, pp. 205 - 224. (paper presentation)

[29] Beneš, Jaromir, Zvelebil, Marek (1999): A historical interactive landscape in the hearth of Europe: the case of Bohemia, p. 74, v: Peter J. Ucko, Robert Layton: The Archeology and Anthropology of Landscape, Routledge, New York, pp. $74-94$.

[30] Clifford, James (1999): Museums as Contact Zones, in: David Boswell and Jessica Evans (ed), Representing the Nation: A Reader: Histories, Heritage and Museums, Routledge, The Open University, pp. 435 - 457.

[31] Susan M. Pearce: Objects as meaning; or narrating the past, in: Susan M. Pearce (ed.): Interpreting objects and Collections, Routledge, 1994, pp. 19 - 29.

[32] Saussure, Ferdinand (1997): Predavanja iz splošnega jezikoslovja, Ljubljana, ISH. 